\title{
SURAT EDARAN DIRJEN DIKTI TENTANG IMBAUAN PEMBELAJARAN DARING DAN SOSIALISASI UNDANG-UNDANG CIPTA KERJA: ANALISIS WACANA KRITIS
}

\author{
(Director General of Higher Education's Circular Letter on Online Learning Appeal \\ and The Socialization of Job Creation Law: A Critical Discourse Analysis)
}

\author{
Tristanti Apriyani $^{1}$, Via Cahyani ${ }^{2}$ \\ ${ }^{1}$ Prodi Sastra Indonesia, Universitas Ahmad Dahlan \\ ${ }^{2}$ Program Pascasarjana, Universitas Gadjah Mada \\ Pos-el: tristanti.apriyani@idlitera.uad.ac.id
}

(Naskah Diterima 26 Januari 2021-Direvisi 16 Agustus 2021-Disetujui 24 September 2021)

\begin{abstract}
This study discusses the structure and characteristics of the Director General of Higher Education's circular letter on the appeal for online learning and socialization of the Job Creation Law. The purpose of this study is to reveal inequality or the existence of domination and marginalized parties through the structure and characteristics of Teun A. van Dijk's critical discourse analysis model. This is a qualitative descriptive research. The results of the study indicate that there are parties who dominate or have power, namely the Ministry of Education and Culture, higher education leaders, and students became those who are marginalized.
\end{abstract}

Keywords: critical discourse analysis, van Dijk, Job Creation Law

\begin{abstract}
Abstrak
Penelitian ini berisi pembahasan tentang struktur dan karakteristik Surat Edaran Dirjen Dikti kepada pimpinan perguruan tinggi mengenai imbauan pembelajaran secara daring dan sosialiasi Undang-Undang Cipta Kerja. Tujuan dari penelitian ini adalah mengungkap ketidaksetaraan atau adanya pihak yang mendominasi dan pihak yang terpinggirkan melalui struktur dan karakteristik analisis wacana kritis model Teun A. van Dijk. Metode yang digunakan dalam penelitian ini adalah metode deskriptif kualitatif. Hasil penelitian menunjukkan bahwa ada pihak yang mendominasi atau berkuasa, yakni Kementerian Pendidikan dan Kebudayaan dan pimpinan perguruan tinggi, dan pihak yang terpinggirkan, yaitu mahasiswa.
\end{abstract}

Kata kunci: analisis wacana kritis, van Dijk, Undang-Undang Cipta Kerja

\section{PENDAHULUAN}

Pandemi yang terjadi saat ini memaksa rakyat Indonesia belajar dan melakukan hal-hal baru. Pemerintah pun memberlakukan kebijakan Pembatasan Sosial Berskala Besar (PSBB) untuk menekan penyebaran Covid-19. Hal ini memaksa semua kegiatan yang dilakukan di luar rumah harus dibatasi, termasuk kegiatan belajar mengajar di perguruan tinggi.

Sejak dikeluarkannya Surat Edaran Nomor 36962/MPK.A/HK/2020 pada tanggal 17 Maret 2020 oleh Menteri Pendidikan dan Kebudayaan, seluruh 
kegiatan belajar mengajar di kampuskampus dilaksanakan secara daring. Hal itu dilakukan sebagai upaya pencegahan penyebaran Covid-19.

Di tengah pandemi yang masih berlangsung, muncul fenomena pengesahan Omnibus Law Undang-Undang Cipta Kerja oleh pemerintah dan DPR. UndangUndang Cipta Kerja itu mendapat penolakan dari sejumlah kalangan, termasuk mahasiswa. Mahasiswa dari berbagai perguruan tinggi ikut serta dalam aksi unjuk rasa yang dilakukan pada tanggal 5 Oktober 2020. Aksi unjuk rasa pun berakhir ricuh dan mencapai puncaknya pada tanggal 8 Oktober 2020.

Hal tersebut mendapat perhatian khusus dari Kementerian Pendidikan dan Kebudayaan (Kemendikbud), dalam hal ini Direktur Jenderal Pendidikan Tinggi (Dirjen Dikti), dengan mengeluarkan surat edaran yang intinya mengimbau mahasiswa untuk tidak ikut berunjuk rasa karena dapat membahayakan kesehatan. Surat Edaran Dirjen Dikti Nomor 1035/E/KM/2020 tentang Imbauan Pembelajaran Secara Daring dan Sosialisasi Undang-Undang Cipta Kerja tersebut ditandatangani oleh Dirjen Dikti, Kemendikbud, Prof. Dr. Nizam, M.Sc., Ph.D. Dosen diminta untuk tetap melaksanakan pembelajaran daring dengan memantau kehadiran dan meningkatkan interaksi pembelajaran dengan mahasiswa secara daring.

Surat edaran tersebut tentu mendapat reaksi dari mahasiswa. Mereka menganggap bahwa sikap Kemendikbud bertolak belakang dengan semangat merdeka belajar dan kampus merdeka. Menurut pembuat surat, kebijakan itu diambil dengan mempertimbangkan situasi yang belum kondusif untuk pembelajaran dan mengimbau mahasiswa tidak turut serta dalam kegiatan unjuk rasa yang dapat membahayakan keselamatan dan kesehatan pada masa pandemi ini.

Dalam surat edaran tersebut teks atau wacana yang dihasilkan menarik untuk dikaji karena mengandung unsur-unsur bahasa, seperti semantik, sintaksis, stilistika, dan retorika. Eriyanto menyebut wacana sebagai kesatuan bahasa yang lengkap dan menduduki posisi lebih besar dari kalimat, baik secara lisan maupun tulisan (Eriyanto, 2001). Defisini wacana yang tertera dalam KBBI adalah satuan bahasa terlengkap yang direalisasikan dalam bentuk karangan atau laporan utuh, seperti novel, buku, artikel, pidato, atau khotbah. Dapat disimpulkan bahwa wacana adalah kesatuan kalimat yang saling berhubungan sehingga dari kesatuan kalimat tersebut terbentuklah makna yang serasi.

Untuk memahami sebuah wacana berkaitan dengan bahasa yang digunakan, diperlukan analisis wacana kritis. Analisis wacana kritis menitikberatkan pada kekuatan dan ketidaksetaraan yang tercipta pada fenomena sosial (van Dijk, 2005). Dikatakan bahwa analisis wacana kritis merupakan proses analisis terhadap bahasa dan penggunaannya yang bertujuan untuk memperoleh deskripsi yang sistematis dan lebih eksplisit tentang apa yang disampaikan (van Dijk, 1988). Tugas analisis wacana kritis adalah menguraikan relasi kuasa, dominasi, dan ketimpangan yang diproduksi dalam sebuah wacana.

Menurut Asmara, seseorang memiliki tujuan berwacana, termasuk menjalankan kekuasaannya (Asmara, 2016). Renkema pun menyebutkan bahwa analisis wacana kritis bertujuan untuk mendeteksi masalah-masalah sosial, terutama masalah diskriminasi, dengan memperhatikan bahasa sebagai faktor penting dalam mewujudkan kuasa pihak tertentu. Tentunya, dalam hal ini analisis wacana kritis mengkaji bahasa sebagai suatu tindakan (Renkema, n.d.).

Van Dijk, seperti yang dikutip Kristina (2020:11), mengemukakan bahwa ada tiga jenis struktur yang tecermin pada sebuah wacana, yakni struktur wacana, struktur pikiran, dan struktur masyarakat. 
Oleh karena prinsip analisisnya yang berfokus pada tindakan, konteks, historis, kekuasaan, dan ideologi, analisis wacana kritis banyak digunakan untuk mengkaji wacana pada disiplin ilmu lain, seperti politik, ras, gender, hegemoni, sosial, dan budaya (van Dijk, 1988).

Hal itu sejalan dengan yang dikemukakan Eriyanto bahwa dalam analisis wacana kritis, wacana tidak semata-mata sebagai studi ilmu bahasa, tetapi berhubungan dengan konteks ilmu lainnya. Bahasa yang digunakan dalam wacana sebagai alat komunikasi dapat memengaruhi cara pelafalan (pronounciation), tata bahasa (grammar), susunan kalimat (syntax), perluasan perbendaharaan kata, hingga mampu mengubah dan mengembangkan percakapan (speech) (Eriyanto, 2001).

Penggunaan bahasa tertentu memiliki implikasi terhadap kemunculan makna tertentu. Begitu pula halnya dengan pemilihan kata dan cara penyajian suatu realitas. Bahasa yang digunakan terkadang tidak transparan, sarat dengan retorika, manipulasi dan penyesatan sehingga banyak wacana yang tidak langsung mengungkapkan maksud penulis (Haryatmoko, 2016). Selain itu, bahasa dapat dijadikan alat untuk mengidentifikasi dari mana dan dari kelompok sosial mana penulis berasal.

Silaswati dan Saleh mengungkapkan bahwa bahasa yang dianalisis bukan menggambarkan aspek bahasa saja, tetapi berusaha untuk menghubungkan dengan konteksnya (Saleh, 2020; Silaswati, 2019). Konteks bahasa yang digunakan dalam surat edaran yang dibuat Dirjen Dikti mengenai imbauan pembelajaran daring dan sosialisasi Undang-Undang Cipta Kerja dipakai untuk kepentingan tertentu, termasuk di dalamnya praktik kekuasaan. Penelitian ini bertujuan mengkaji konstruksi wacana yang terdapat dalam surat edaran tersebut dengan menggunakan analisis wacana kritis model Teun A. van
Dijk dengan fokus kajian pada struktur makro, super struktur, dan struktur mikro. Karakteristik analisis wacana kritis, yakni tindakan, konteks, historis, kekuasaan, dan ideologi, juga dibahas dalam penelitian ini.

\section{METODE PENELITIAN}

Penelitian ini merupakan penelitian deskriptif kualitatif. Data deskriptif, menurut Moleong, berbentuk diksi tertulis mengenai kondisi dan fenomena, baik individu maupun kelompok, yang diamati. Fakta dan karakteristik objek atau subjek yang diteliti secara sistematis digambarkan secara tepat dalam penelitian deskriptif ini (Moleong, 2015).

Data yang dianalisis dalam penelitian ini berupa teks yang tertera dalam Surat Edaran Dirjen Dikti tentang Pembelajaran Daring dan Sosialisasi Undang-Undang Cipta Kerja yang diterbitkan pada tanggal 9 Oktober 2020.

Teknik pengumpulan data yang dilakukan ialah simak dan catat. Langkah pertama dalam analisis data adalah mengklasifikasi data kebahasaan yang memuat praktik diskursif. Hal ini bermaksud agar strategi kebahasaannya dapat dirumuskan. Langkah kedua adalah dengan menginterpretasikan motif atau maksud terselubung di balik strategi kebahasaan yang digunakan Kemendikbud berdasarkan konteks situasi dan latar wacana yang relevan.

\section{PEMBAHASAN}

\section{Struktur Wacana Surat Edaran Dirjen Dikti}

\section{Struktur Makro}

Struktur makro pada teori van Dijk mengamati tematik atau tema/topik yang diusung dalam suatu teks (van Dijk, 2005). Tema adalah sebuah gagasan 
utama atau gagasan inti, ringkasan yang mendasari suatu teks.

Berdasarkan analisis struktur makro, ditemukan tema atau topik teks, yaitu imbauan pembelajaran secara daring dan sosialiasi Undang-Undang Cipta Kerja. Sejalan dengan yang dikemukakan Haryatmoko, struktur makro menunjukkan bahwa kajian wacana kritis diawali dengan pencarian tema atau topik dan makna (Haryatmoko, 2016).

\section{Super Struktur}

Skematik atau super struktur adalah strategi yang dilakukan untuk mendukung makna umum dengan memberikan sejumlah alasan pendukung. Alasan pendukung ini dirumuskan dalam pendahuluan, isi, dan penutup.

\section{Pendahuluan}

Pendahuluan pada surat edaran Ditjen Dikti tersebut berisi pembukaan surat yang membahas kondisi pembelajaran yang kurang kondusif. Hal tersebut ditunjukkan oleh kalimat berikut.

"Memperhatikan situasi akhir-akhir ini yang kurang kondusif untuk pembelajaran, terutama terkait dengan tanggapan atas akan diterbitkannya Undang-Undang (UU) Cipta Kerja, dengan ini kami mohon Pimpinan Perguruan Tinggi untuk melaksanakan hal-hal berikut."

\section{Isi berita}

Isi berita berkisar pada imbauan Dirjen Dikti agar perguruan tinggi tetap melaksanakan pembelajaran jarak jauh (PJJ) dan mengimbau mahasiswa untuk tidak ikut serta dalam demonstrasi atau unjuk rasa di tengah masa pandemi.

\begin{abstract}
Penutup
Penutup surat edaran tersebut berisi informasi mengenai sosialisasi UndangUndang Cipta Kerja yang diperbarui secara rutin dan dapat diakses melalui tautan https://ldikti6.id/wpcontent/uploads/2020/10/1035.pdf dan ucapan terima kasih.
\end{abstract}

\section{Struktur Mikro}

Struktur mikro mengamati makna yang ingin ditekankan dalam sebuah teks. Surat edaran tersebut berisi aspek semantik, sintaksis, stilistika, dan retorika teks sesuai dengan rumusan van Dijk.

\section{Semantik}

\section{Latar}

Latar pembuatan surat edaran tersebut adalah kondisi pembelajaran yang kurang kondusif, terutama saat diterbitkannya Undang-Undang Cipta Kerja. Unjuk rasa yang terjadi saat pandemi dinilai dapat membahayakan mahasiswa dan masyarakat luas.

\section{Detail}

Berdasarkan poin-poin dalam surat edaran itu, penulis menarik simpulan bahwa inti surat edaran tersebut adalah pimpinan perguruan tinggi diminta mengimbau mahasiswa untuk tetap melaksanakan pembelajaran jarak jauh dan tidak mengikuti unjuk rasa berkaitan dengan Undang-Undang Cipta Kerja.

Poin 6 dalam surat edaran tertulis sebagai berikut.

"Menginstruksikan para dosen untuk senantiasa mendorong mahasiswa melakukan kegiatan intelektual dalam mengkritisi UU Cipta Kerja maupun produk kebijakan lainnya dan tidak memprovokasi mahasiswa untuk mengikuti/mengadakan kegiatan demonstrasi/unjuk rasa/penyampaian 
aspirasi yang dapat membahayakan keselamatan dan kesehatan para mahasiswa/i."

Orang tua/wali pun diimbau untuk memantau putra-putrinya agar tetap melaksanakan pembelajaran jarak jauh. Hal itu tercantum dalam poin 7 berikut.

"Mengimbau para orang tua/wali
mahasiswa untuk turut menjaga
putra/putrinya agar melakukan
pembelajaran dari tempat tinggal
masing-masing."

\section{Maksud}

Tujuan secara eksplisit dalam surat edaran tersebut telah dijelaskan pada bagian detail sebelumnya, sedangkan tujuan secara implisit ditunjukkan oleh kalimat berikut.

"Menginstruksikan para dosen untuk senantiasa mendorong mahasiswa melakukan kegiatan intelektual dalam mengkritisi UU Cipta Kerja, maupun produk kebijakan lainnya dan tidak memprovokasi mahasiswa untuk mengikuti Imengadakan kegiatan demonstrasi/unjuk rasa/penyampaian aspirasi yang dapat membahayakan keselamatan dan kesehatan para mahasiswa/i."

Secara tersirat kalimat tersebut menunjukkan bahwa RUU Cipta Kerja tidak boleh menganggu proses pembelajaran. Mahasiswa pun tidak diperkenankan mengikuti demonstrasi. Oleh karena itu, pimpinan perguruan tinggi diperintahkan tetap melaksanakan pembelajaran jarak jauh.

\section{Praanggapan}

Praanggapan merupakan elemen wacana yang digunakan untuk mendukung makna suatu teks dengan cara memberikan premis yang dipercaya kebenarannya. Praanggapan merupakan fakta yang belum terbukti kebenarannya, tetapi dijadikan dasar untuk mendukung gagasan tertentu. Praanggapan dalam surat edaran tersebut terurai dalam tabel di bawah ini.

Tabel 1 Praanggapan

\begin{tabular}{|c|c|}
\hline Tanpa Praanggapan & nggapan \\
\hline $\begin{array}{l}\text { Tetap melaksanakan pembelajaran secara } \\
\text { daring/Pembelajaran Jarak Jauh (PJJ) dan } \\
\text { para mahasiswa melaksanakan } \\
\text { pembelajaran dari tempat tinggal masing- } \\
\text { masing. }\end{array}$ & $\begin{array}{l}\text { Pimpinan perguruan tinggi mengimbau } \\
\text { mahasiswanya agar tetap melaksanakan } \\
\text { pembelajaran secara daring/Pembelajaran Jarak } \\
\text { Jauh (PJJ) karena jika tidak dilaksanakan } \\
\text { pembelajaran secara daring maka mahasiswa } \\
\text { akan turut serta dalam unjuk rasa mengenai } \\
\text { Undang-Undang Cipta Kerja. }\end{array}$ \\
\hline $\begin{array}{l}\text { Mengimbau para mahasiswa/i untuk tidak } \\
\text { turut serta dalam kegiatan } \\
\text { demonstrasi/unjuk rasa/penyampaian } \\
\text { aspirasi yang dapat membahayakan } \\
\text { keselamatan dan kesehatan para } \\
\text { mahasiswa/i di masa pandemi ini. }\end{array}$ & $\begin{array}{l}\text { Pimpinan perguruan tinggi mengimbau } \\
\text { mahasiswanya untuk tidak turut serta dalam } \\
\text { kegiatan demonstrasi/unjuk rasa/ penyampaian } \\
\text { aspirasi karena jika mahasiswa turut serta dalam } \\
\text { unjuk rasa, proses penetapan Undang-Undang } \\
\text { Cipta Kerja dapat terganggu. }\end{array}$ \\
\hline
\end{tabular}




\begin{tabular}{lll}
\hline Membantu menyosialisasikan isi Undang- & Pimpinan perguruan tinggi membantu \\
Undang Cipta Kerja dan mendorong & menyosialisasikan isi Undang-Undang Cipta \\
kajian-kajian akademis objektif atas & Kerja dan mendorong kajian-kajian akademis \\
undang-undang tersebut. Hasil pemikiran & objektif atas undang-undang tersebut. Hasil \\
dan aspirasi dari kampus hendaknya & pemikiran dan aspirasi dari kampus hendaknya \\
disampaikan kepada pemerintah maupun & disampaikan kepada pemerintah maupun DPR \\
DPR melalui mekanisme yang ada & melalui mekanisme yang ada dengan cara-cara \\
dengan cara-cara yang santun. & yang santun. Mahasiswa yang tidak paham betul \\
& dengan undang-undang cipta kerja dan \\
& melakukan demonstrasi akan menyebabkan \\
& kericuhan yang dapat merugikan negara. \\
\hline
\end{tabular}

\section{Nominalisasi}

Nominalisasi mengkaji cara komunikator memandang objek sebagai satuan yang tunggal dan berdiri sendiri atau sebagai suatu kelompok komunitas. Dalam surat edaran tersebut, Dirjen Dikti sebagai komunikator memandang objek sebagai kelompok komunitas, yakni mahasiswa yang kerap melakukan demonstrasi atau unjuk rasa. Hal tersebut tertera dalam kalimat berikut.

"Hasil pemikiran dan aspirasi dari kampus hendaknya disampaikan kepada Pemerintah maupun DPR melalui mekanisme yang ada dengan cara-cara yang santun."

Kata hendaknya pada kalimat tersebut menyiratkan bahwa mahasiswa sering menyampaikan aspirasinya dengan cara demonstrasi dan melakukannya dengan cara-cara yang tidak santun.

\section{Sintaksis}

Sintaksis merupakan strategi analisis wacana kritis untuk menampilkan diri sendiri secara positif dan lawan secara negatif. Hal tersebut ditempuh dengan cara manipulasi politik, seperti pemakaian kata ganti, aturan tata kata, pemakaian kategori sintaksis yang spesifik, pemakaian kalimat aktif atau pasif, peletakan anak kalimat, pemakaian kalimat yang kompleks, dan sebagainya (Sobur, 2006).

\section{Bentuk Kalimat}

Bentuk kalimat merupakan aspek sintaksis yang berkaitan dengan cara berpikir logis. Bentuk kalimat dalam hal ini tidak hanya persoalan teknis kebenaraan tata bahasa, tetapi juga cara menentukan makna yang dibentuk oleh susunan kalimat. Seseorang akan menduduki posisi subjek dari pernyataan di dalam kalimat yang berstruktur aktif. Dalam kalimat pasif, seseorang akan menduduki posisi objek dari pernyataan.

Tabel 2 Bentuk Kalimat

\begin{tabular}{ll}
\hline Aktif & Pasif \\
\hline Kalimat asli & Pemasifan \\
$\begin{array}{l}\text { Petinggi perguruan tinggi mengimbau para } \\
\text { mahasiswa/i untuk tidak turut serta dalam }\end{array}$ & $\begin{array}{l}\text { Para mahasiswa/i diimbau untuk tidak turut } \\
\text { serta dalam kegiatan demonstrasi/unjuk } \\
\text { kegiatan demonstrasi/unjuk rasa/ } \\
\text { penyampaian aspirasi. }\end{array}$ \\
\hline
\end{tabular}


Analisis

Makna yang muncul dalam kedua kalimat ini berbeda. Kedua kalimat tersebut merupakan kalimat positif. Kalimat aktif dipilih dalam teks surat edaran tersebut karena pimpinan perguruan tinggi sebagai subjek ditonjolkan pada awal kalimat. Unsur itu menduduki posisi yang penting yang kemudian dinilai memiliki citra baik oleh khalayak.

Pengaktifan
Hendaknya mahasiswa menyampaikan hasil
aspirasi kepada pemerintah maupun DPR
melalui mekanisme yang ada dengan cara-
cara yang santun. Analisis

Dalam kalimat tersebut kalimat pasif dipilih agar mahasiswa sebagai objek yang disamarkan terkesan negatif. Jika menyampaikan aspirasi, mereka akan melakukannya dengan cara yang tidak sopan atau anarkistis. Kalimat aktif tidak digunakan karena akan menimbulkan citra baik terhadap mahasiswa.

\section{Koherensi}

Koherensi adalah pertalian atau hubungan antarkata atau kalimat dalam sebuah teks. Dua buah kalimat yang menggambarkan fakta yang berbeda dihubungkan sehingga tampak koheren. Pernyataan berikut menampakkan hal itu.

\begin{abstract}
"Menginstruksikan para dosen untuk senantiasa mendorong mahasiswa melakukan kegiatan intelektual dalam mengkritisi Undang-Undang Cipta Kerja, maupun produk kebijakan lainnya dan tidak memprovokasi mahasiswa untuk mengikuti/mengadakan kegiatan demonstrasi/unjuk rasa/penyampaian aspirasi yang dapat membahayakan keselamatan dan kesehatan para mahasiswa/i.",
\end{abstract}

Pada awal kalimat Dirjen Dikti memberi arahan kepada dosen untuk mendorong mahasiswa melakukan kegiatan intelektual dalam mengkritisi UndangUndang Cipta Kerja atau produk kebijakan lainnya. Di sini tampak bahwa Dirjen Dikti memberikan arahan agar mahasiswa melakukan kegiatan intelektual dan tidak melakukan aksi demonstrasi atau unjuk rasa. Dalam kalimat selanjutnya, koherensi

\section{Kalimat asli}

Hasil pemikiran dan aspirasi dari kampus hendaknya disampaikan kepada pemerintah maupun DPR melalui mekanisme yang ada dengan cara-cara yang santun. 
mengurangi kritik serta oposisi kepada diri sendiri. Kata ganti kami juga digunakan untuk menciptakan jarak dan memisahkan pihak Dirjen Dikti dengan pihak perguruan tinggi dan mahasiswa.

\section{Stilistika}

Pusat perhatian stilistika adalah gaya bahasa, yaitu cara yang digunakan komunikator untuk menyatakan maksudnya dengan menggunakan bahasa sebagai sarana. Gaya bahasa sebagai bagian dari diksi berhubungan dengan ungkapan-ungkapan yang individual dan memiliki nilai artistik yang tinggi (van Dijk, 1985).

Gaya bahasa yang dipakai dalam surat edaran tersebut adalah eufemisme. Eufemisme dipilih Dirjen Dikti ketika ingin menghaluskan perintah-perintah yang harus dilaksanakan. Penghalusan makna dilakukan dengan cara memilih kata atau istilah yang mempunyai konotasi sopan, menyenangkan, tidak menyinggung, dan konotasi positif lainnya. Hal itu terdapat pada pemilihan verba menjaga, melaksanakan, memantau, mengimbau, membantu, dan menginstruksikan.

Ungkapan "Mengimbau para mahasiswa/i untuk tidak turut serta dalam kegiatan demonstrasi/unjuk rasa/penyampaian aspirasi" terasa lebih sopan daripada "Mahasiswa dilarang mengikuti kegiatan demonstrasi/unjuk rasa/penyampaian aspirasi". Dengan diksi tersebut, pembuat surat ingin menunjukkan kepada khalayak bahwa perintah yang dimaksudkan tidak terkesan mengekang.

\section{Retorika Grafis}

Elemen grafis pada wacana merupakan bagian yang dianggap penting atau ditonjolkan dari sebuah teks. Bagian yang ditonjolkan dalam teks surat edaran tersebut ditulis menggunakan huruf kapital, yakni Pimpinan Perguruan Tinggi; Pembelajaran Jarak Jauh; dan Direktorat Pembelajaran dan Kemahasiswaan. Pemakaian huruf kapital tersebut merupakan penekanan khalayak menggarisbawahi hal-hal yang dianggap penting dan harus difokuskan.

\section{Karateristik Surat Edaran}

\section{Tindakan}

Wacana dipahami sebagai sebuah tindakan (action) atau sebuah bentuk interaksi. Dalam hal ini, wacana bertujuan memengaruhi, mendebat, membujuk, menyangga, bereaksi, dan sebagainya (van Dijk, 1985). Pada teks surat edaran terdapat beberapa imbauan kepada pimpinan perguruan tinggi untuk melaksanakan beberapa perintah. Perintah-perintah tersebut dikategorikan sebagai tindakan karena teks tersebut bukan hanya sebuah wacana, melainkan juga bentuk memengaruhi, memerintah, mengajak, dan melarang.

\section{Konteks}

Konteks adalah unsur terpenting yang mendasari sebuah wacana. Konteks wacana dapat berupa latar, kondisi, situasi, dan peristiwa. Konteks yang melatarbelakangi surat edaran tersebut adalah banyaknya mahasiswa yang melakukan unjuk rasa menolak pengesahan Undang-Undang Cipta Kerja di Indonesia. Oleh karena itu, surat edaran tersebut menegaskan bahwa pembelajaran jarak jauh tetap harus dilaksanakan agar demonstrasi atau unjuk rasa yang dilakukan oleh mahasiswa dapat diminimalkan. 


\section{Historis}

Sebuah teks dapat dipahami dalam konteks historis ketika teks itu diciptakan. Karakteristik historis pada surat edaran tersebut dimulai dari pembahasan Rancangan Undang-undang Cipta Kerja pada tahun 2019 yang menyebabkan pro dan kontra di masyarakat Indonesia.

Sejak undang-undang tersebut dirancang, banyak mahasiswa yang melakukan demonstrasi. Salah satunya ialah unjuk rasa Gejayan Memanggil I pada 23 September 2019. Kemudian, pada 9 Maret 2020 mahasiswa dan elemen masyarakat kembali menggelar aksi unjuk rasa Gejayan Memanggil II. Mahasiswa di kota lain pun banyak yang menggelar unjuk rasa serupa.

Di sisi lain, bulan Maret 2020 di Indonesia mulai terjadi pandemi Covid19. Pada 5 Oktober 2020, undangundang tersebut disahkan oleh pemerintah. Untuk meminimalkan terjadinya demonstrasi, Dirjen Dikti mengeluarkan surat edaran mengenai imbauan pembelajaran secara daring dan sosialisasi Undang-Undang Cipta Kerja tersebut.

\section{Kekuasaan}

Analisis wacana tidak memandang wajar dan netral setiap wacana, baik dalam bentuk teks, percakapan, maupun lainnya. Wacana merupakan bentuk pertarungan kekuasaan. Konsep kekuasaan merupakan salah satu kunci hubungan antara wacana dan masyarakat.

Dalam teks surat edaran Dirjen Dikti, pihak yang dominan dan memiliki kuasa adalah pihak Kemendikbud, dalam hal ini Dirjen Dikti. Pihak yang berada di bawah Kemendikbud adalah pimpinan perguruan tinggi, sedangkan pihak yang terpinggirkan adalah mahasiswa.
Perintah-perintah dari Kemendikbud kepada pimpinan perguruan tinggi secara tidak langsung merupakan sebuah alat untuk membungkam suara mahasiswa. Hal itu disamarkan oleh adanya perintah pembelajaran jarak jauh.

Selanjutnya, ungkapan yang tertera dalam poin 5, "Hasil pemikiran dan aspirasi dari kampus hendaknya disampaikan kepada Pemerintah maupun DPR melalui mekanisme yang ada dengan cara-cara yang santun" dinilai bertentangan dengan realitas yang terjadi sebelumnya. Unjuk rasa Gejayan Memanggil I terbukti kondusif tanpa kerusuhan.

\section{Ideologi}

Ideologi merupakan konsep sentral dalam analisis wacana kritis. Dikatakan demikian karena teks, percakapan, dan lainnya merupakan bentuk dari praktik ideologi atau pencerminan ideologi tertentu. Ideologi dalam teks surat edaran tersebut adalah tentang cara Kemendikbud menggiring opini khalayak untuk menyetujui isi keseluruhan teks. Surat edaran dimanfaatkan Kemendikbud sebagai sarana untuk mendominasi dan menunjukkan kuasa.

\section{PENUTUP}

Hasil analisis teks surat edaran Dirjen Dikti sejalan dengan teori van Dijk. Teks itu terdiri atas struktur makro, super struktur, dan struktur mikro. Ditemukan beberapa pihak yang mendominasi, yakni Kemendikbud, dalam hal ini Dirjen Dikti dan pimpinan perguruan tinggi. Sementara itu, pihak yang terpinggirkan adalah mahasiswa.

Dalam teks tersebut terdapat larangan bagi mahasiswa untuk mengikuti kegiatan unjuk rasa. Hal tersebut secara tidak langsung 
merupakan bentuk pembungkaman terhadap suara mahasiswa. Teks tersebut juga dapat memengaruhi pemikiran khalayak bahwa seolah-olah setiap unjuk rasa yang dilakukan mahasiswa berjalan buruk dan menyebabkan kericuhan. Melalui surat edaran itu opini khalayak digiring untuk setuju dengan ideologi Dirjen Dikti dan menganggap teks tersebut absah dan benar.

\section{DAFTAR PUSTAKA}

Asmara, R. (2016). Strategi Kebahasaan Presiden Jokowi dalam Menanamkan Ideologi dan Manifesto Pemerintahan. Litera, 15, 379-388. https://doi.org/10.21831/ltr.v15i2.1 1836

Eriyanto. (2001). Analisis Wacana: Pengantar Analisis Teks Media. Yogyakarta:LKiS.

Haryatmoko. (2016). Critical Discourse Analysis (Analisis Wacana Kritis). Jakarta:Raja Grafindo Persada.

Moleong, L. J. (2015). Metodologi Penelitian Kualitatif. Bandung:Remaja Rosdakarya.

Renkema, J. (n.d.). Introduction to Discourse Studies. Amsterdam: John Benjamin Publishing.

Saleh, R. (2020). Analisis Wacana Kritis "Hukuman Salah Alamat" pada Acara Mata Najwa. Suar Betang, 15(2), 181-197. https://doi.org/10.26499/surbet.v15 i2.205

Silaswati, D. (2019). Analisis Wacana Kritis dalam Pengkajian Wacana. Metamorfosis, 12(1), 1-10.

Van Dijk, T. A. (1985). Semantic Discourse Analysis. Discourse Theory and Practice, 2.

Van Dijk, T. A. (1988). News as Discourse. New Jersey: Lawrence Erlbaum Associates, Inc. Publishers.
Van Dijk, T. A. (2005). Contextual Knowledge Management in Discourse Production. In R. Wodak \& P. Chilton (Eds.), A New Agenda in (Critical) Discourse Analysis: Theory, Methodology and Interdisciplinarity (pp. 71100). London/New York: John Benjamin Publishing Company. https://doi.org/10.1075/dapsac.13.0 7dij 